\title{
Performance based design of masonry infilled reinforced concrete frames for near-field earthquakes
}

\author{
A. $\operatorname{Madan}^{1}$, D. $\operatorname{Das}^{2} \&$ A. Hashmi ${ }^{3}$ \\ ${ }^{I}$ Department of Civil Engineering, Indian Institute of Technology, \\ New Delhi, India \\ ${ }^{2}$ Department of Civil Engineering, Durgapur, India \\ ${ }^{3}$ Structural Engineer, Gulf Region
}

\begin{abstract}
Performance Based Design (PBD) is an iterative exercise in which a preliminary trial design of the building structure is selected and if the selected trial design of the building structure does not conform to the desired performance objective, the trial design is revised. In this context, development of a fundamental approach for performance based seismic design of masonry infilled frames with minimum number of trials is an important objective. The paper presents a plastic design procedure based on the energy balance concept for PBD design of multi-story multi-bay masonry infilled reinforced concrete $(\mathrm{R} / \mathrm{C})$ frames subjected to nearfield earthquakes. The proposed energy based plastic design procedure was implemented for trial performance based seismic design of representative masonry infilled reinforced concrete frames with various practically relevant distributions of masonry infill panels over the frame elevation. Non-linear dynamic analyses of the trial PBD of masonry infilled R/C frames was performed under the action of near-field earthquake ground motions. The results of non-linear dynamic analyses demonstrate that the proposed energy method is effective for performance based design of masonry infilled $\mathrm{R} / \mathrm{C}$ frames under near-field as well as far-field earthquakes.

Keywords: masonry infilled frame, energy methods, near-fault ground motions, pushover analysis, nonlinear dynamic analysis, seismic demand.
\end{abstract}




\section{Introduction}

In the recent past, near-field earthquake ground motions with large velocity pulses have caused extensive damage to civil engineering structures. Unlike farfield earthquake ground motion records a ground motion recorded in the nearfield region of a strike-slip earthquake (i.e., near the fault rupture of the earthquake) exhibits distinctive short duration long period velocity pulses with large peak ground velocities and accelerations $[1,2]$. The force based design methodology followed by the current seismic design codes may be inherently deficient in ensuring the safety of building structures in such cases. In case of a masonry infilled reinforced concrete $(\mathrm{R} / \mathrm{C})$ framed building with an irregular distribution of masonry panels over the frame elevation, the seismic vulnerability of the building in the event of near-field earthquakes would be further multiplied.

\section{Research significance}

A review of literature on performance-based seismic engineering (PBSE) of building structures indicates that there is no reported research study on performance based design of masonry infilled reinforced concrete $(\mathrm{R} / \mathrm{C})$ frames using the energy approach. Moreover, none of the reported research studies on PBD of moment resisting frames using energy methods focus on the seismic performance of the frame under the action of near-field earthquakes. The paper presents an energy method for PBD of masonry infilled R/C frames subjected to near field earthquakes considering the commonly encountered seismically vulnerable distributions of masonry infill panels over the frame elevation, such as those in which the infill panels are discontinued at the ground level for functional purposes (e.g. providing parking spaces at the ground level) thus resulting in a 'soft story' at that level. One of the objectives of the study is to demonstrate the efficacy of the proposed energy method for PBD of masonry infilled R/C frames under the action of near-field as well as far-field earthquakes considering the influence of the distribution of masonry infill panels over the frame elevation on the seismic vulnerability of the frame.

\section{Plastic design of multi-story multi-bay masonry infilled $\mathrm{R} / \mathrm{C}$ frames based on energy balance concept}

Based on the energy balance formulations available in literature [3-7], a plastic design procedure is proposed in the present study for the above mentioned PBD. The proposed plastic design procedure using the energy balance concept is based on the following additional assumptions:

(i) The plasticity in the $\mathrm{R} / \mathrm{C}$ frame elements is assumed to be concentrated at the plastic hinges for purposes of arriving at the first trial performance based design. 
(ii) The global yield mechanism of the multi-story multi-bay frame shown in Figure 1 (a) that is selected for the formulation of the plastic design procedure is the dominant plastic collapse mode of the masonry infilled $\mathrm{R} / \mathrm{C}$ frame. The assumption is realistic if the transverse shear reinforcement in the $\mathrm{R} / \mathrm{C}$ frame is designed and detailed to prevent shear failure of the $\mathrm{R} / \mathrm{C}$ frame elements due to concentrated shear forces induced by the infill panels at the frame-infill interface, particularly near the beam-column joints.

(iii) The stiffness degradation, strength deterioration and hysteretic energy dissipation in the infill panels under cyclic load reversals during the earthquake may be neglected in the energy based plastic design. The assumption should result in conservative design since the lateral strength of the masonry infills is neglected in the plastic design process while the lateral stiffness and yield deformation of the masonry infilled $\mathrm{R} / \mathrm{C}$ frame is considered in the proposed methodology taking into account the structural contribution of masonry infills.

For purposes of deriving the design input seismic energy as provided by Housner [4], the design pseudo-velocity (PSV) spectrum can be obtained [Figure 1(b)] using the elastic design pseudo-acceleration (PSA) spectrum provided by the seismic design codes as follows:

$$
S_{v}=\frac{T}{2 \pi} a g
$$

where, $\mathrm{T}$ is the fundamental time period, $g$ is acceleration due to gravity and $a$ is the peak PSA, normalized with respect to $g$, which can be obtained from the elastic design PSA spectrum of the Indian seismic design code [8].

The design seismic base shear and earthquake forces at various levels are obtained using equations available in literature $[5,6]$, based on the assumption that the selected global yield mechanism shown in Figure 1(a) is maintained during the entire earthquake excitation. For the selected global yield mechanism [Figure 1(a)], the assumption may be explicitly incorporated in the design process by rewriting the equilibrium equation for the frame as follows:

$$
\sum_{i=1}^{n} F_{i} h_{i}=\sum_{i=1}^{n} 2 n_{b} \beta_{i} M_{p b r}+\left(n_{b}+1\right) M_{p c}
$$

where, in this case, $F_{i}$ is the design earthquake force at level $i$ evaluated (as explained earlier), $n_{b}$ is the number of bays, $M_{p b r}$ is the common reference plastic moment for beams, $\beta_{i}$ is a factor for proportioning the beam strength at level $i$, $M_{p c}$ is the plastic moment of the columns at the base. 


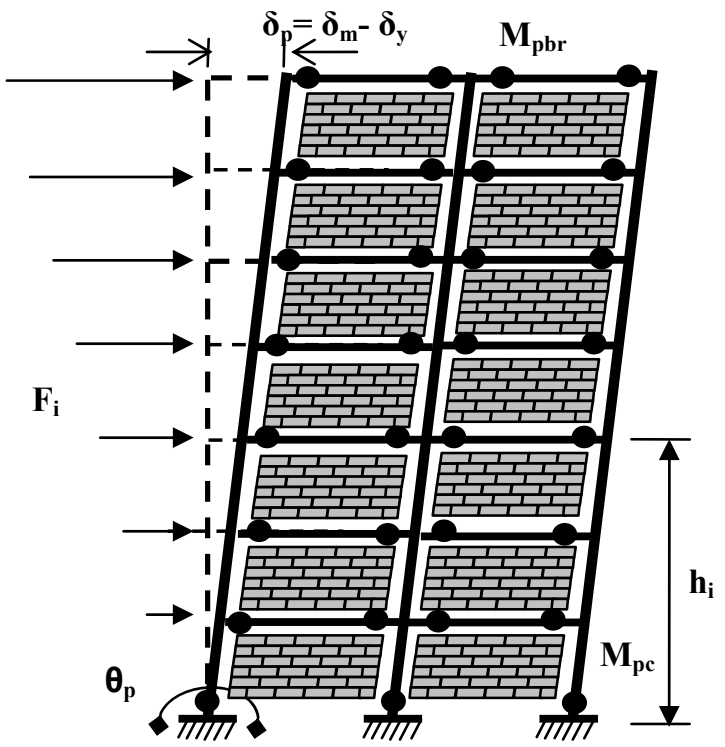

(a)

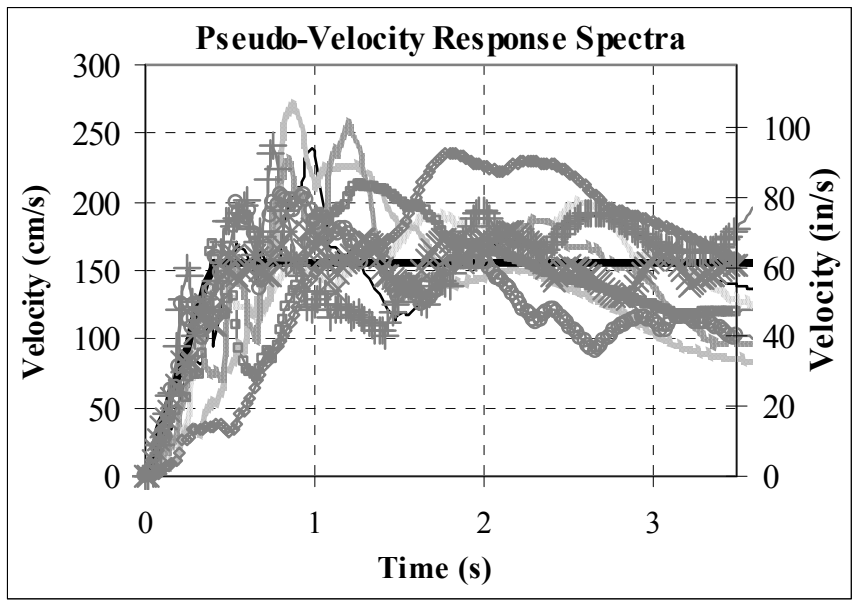

(b)

Figure 1: Key components of the energy balance concept: (a) multi bay frame with selected global plastic mechanism and (b) pseudo-velocity response spectra of the scaled earthquake ground motion records and design response spectrum. 
The beam proportioning factors $\beta_{i}$ in Equation (2) represents the ratio of the plastic moment capacity of beams at level $i$ to a reference plastic moment $M_{p b r}$ for the beams. Assuming suitable values of the proportioning factors $\beta_{i}$ and the plastic moment $M_{p c}$ of the columns at the base, Equation (2) can be solved to determine the common reference plastic moment $M_{p b r}$ for the beams, the only unknown variable in the equation. The methodology proposed by Leelataviwat $e t$ al. [3] was used in the present study to select the beam proportioning factors $\beta_{i}$ and the plastic moment $M_{p c}$ of the columns in Equation (2).

\section{Performance based seismic design of masonry infilled $\mathrm{R} / \mathrm{C}$ frames using the energy approach}

The proposed method was implemented for trial PBD of multi-story multi-bay frames considering the representative frame geometries as shown and explained in Table 1. For purposes of comparison, the frames are also designed in compliance with the prevalent code-specified force based design criteria.

\subsection{Estimation of yield drifts of masonry infilled $R / C$ frames for energy based plastic design}

The proposed energy approach requires estimation of the yield drifts of the frames, since the yield drift of the frame equals the maximum elastic rotation for the yield mechanism of the frame. The yield drifts were estimated in the present study by performing a non-linear pushover analysis of the code-compliant designs of the infilled frames. The $\mathrm{R} / \mathrm{C}$ frame with the representative geometry [Table 1] was designed in compliance with the force based design criteria specified by the current Indian seismic design code [8] for the various practically relevant distributions of masonry infill panels over the frame elevation. Figure 2(a) presents the design dimensions and reinforcement details of the codecompliant $\mathrm{R} / \mathrm{C}$ frame.

Force-controlled non-linear static analysis (pushover analysis) of the codecompliant designs of masonry infilled $\mathrm{R} / \mathrm{C}$ frames was performed by applying an incrementally increasing inverted triangular (linear) variation of lateral story forces considering the structural contribution of the masonry infill panels. The pushover analysis is based on rational and realistic non-linear macro-element models for the frame elements and masonry infills [9, 10]. Figure 2(b) illustrates the inelastic static lateral force-displacement response determined from the nonlinear pushover analysis of the $\mathrm{R} / \mathrm{C}$ frame for the different distributions of masonry infill. It may be noted that the lateral force and displacement in the plot are normalized with respect to the weight and height, respectively, of the frame, thus resulting in a plot of the horizontal seismic base shear coefficient versus the normalized top drift of the structure. The figure also shows the idealized trilinear capacity curves of the $\mathrm{R} / \mathrm{C}$ frame for the different distribution of masonry infills. The point of initiation of the last linear branch of the idealized curves is 
identified as the yield point and the corresponding deformation as the normalized yield deformation or the yield drift of the frame. It is apparent from Figure 2(b) that the distribution of masonry infill panels over the frame elevation significantly influences the yield drift of the $\mathrm{R} / \mathrm{C}$ frame. It can be observed from the figure that the different distributions of masonry infill panels over the frame elevation considered in the present study may be ranked in the decreasing order of yield drift as: (i) bare frame (ii) masonry infilled frame with no infills at the ground level (iii) masonry infill frame with partially infilled ground story (iv) completely infilled frame.
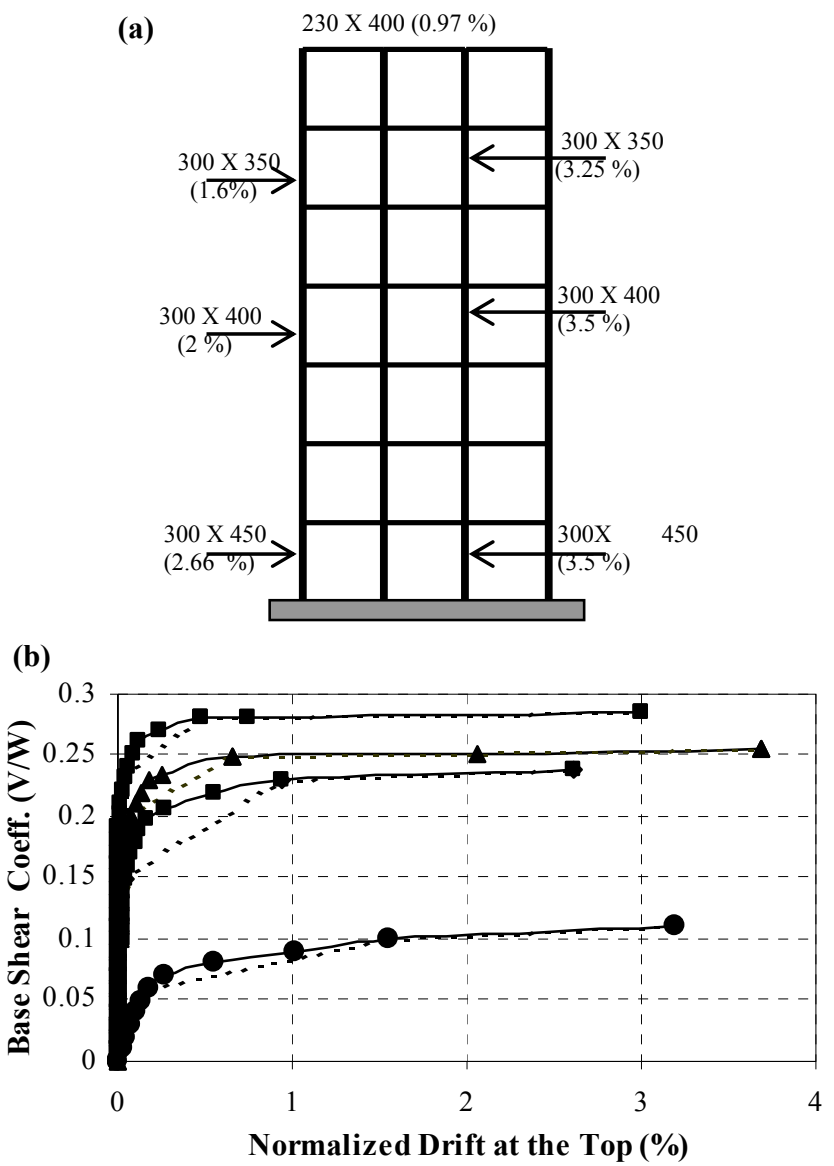

Figure 2: Design dimensions and details and capacity curves of code compliant $\mathrm{r} / \mathrm{c}$ frame: (a) dimensions and reinforcement details of the code-compliant $\mathrm{r} / \mathrm{c}$ frame and (b) capacity curves for the codecompliant masonry infilled $\mathrm{r} / \mathrm{c}$ frames. 
Table 1: Design Variables Computed in Course of the Proposed Energy Based Plastic Design Procedure for a Trial Performance Based Design of the Masonry Infilled R/C Frames with Target Drift of $2 \%$.

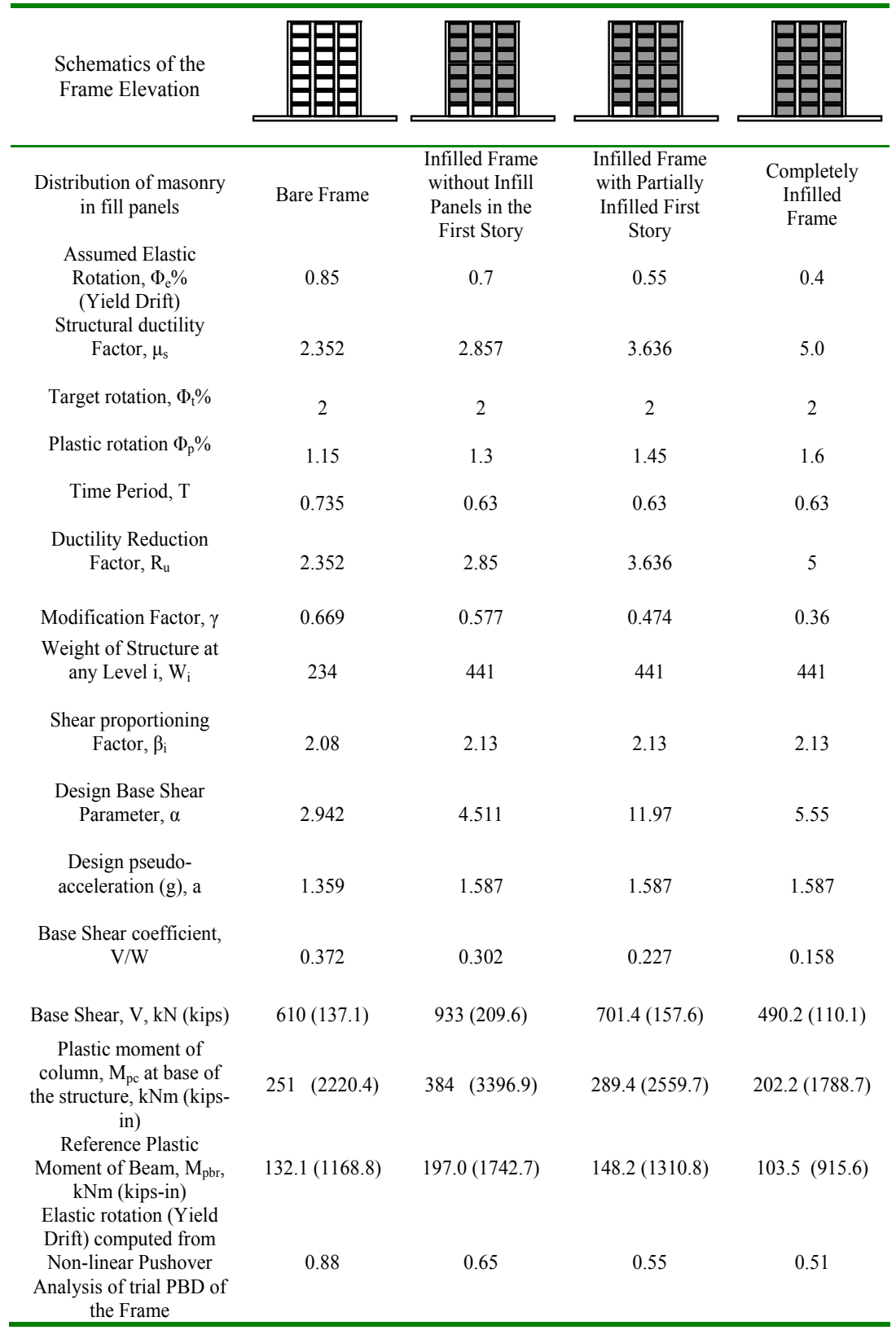




\subsection{Energy based plastic design of the representative multi-story multi-bay masonry infilled $\mathrm{R} / \mathrm{C}$ frames for target performance levels}

In order to validate the proposed PBD methodology using the energy approach, the $\mathrm{R} / \mathrm{C}$ frame with the representative geometry shown in Figure 2(a) was designed using the proposed energy based plastic design procedure for the different distributions of masonry infill panels mentioned in a previous section. As the design is performance based, selecting a target drift is the foremost step in the design process. The masonry infilled $\mathrm{R} / \mathrm{C}$ frames were designed for target inter-story drifts of $1 \%, 2 \%$ and $4 \%$ corresponding to the immediate occupancy (IO), life safety (LS) and collapse prevention (CP) performance limit states, respectively, in accordance with global acceptance criteria defined by ATC-40 [11] and FEMA-356 [12]. Table 1 summarizes the values of the salient design variables computed using the proposed energy based plastic design procedure for a specified target rotation of $2 \%$. The implementation of the proposed procedure is demonstrated in the present paper by selecting a target drift of $2 \%$.

As mentioned in Table 1, the assumed elastic rotations (i.e. yield drifts) estimated from non-linear pushover analysis are $0.4 \%, 0.7 \%, 0.55 \%$ and $0.85 \%$ for the four different masonry infill panel distributions. The target rotation is specified as $2 \%$ for purposes of performance based design. Thus, the plastic rotations are estimated as $1.6 \%, 1.3 \%, 1.45 \%$ and $1.15 \%$ respectively for the four cases, respectively. The structural ductility factor was estimated as the ratio of the ultimate or target rotation to the assumed elastic rotation of the frame. The natural time periods of the masonry infilled $\mathrm{R} / \mathrm{C}$ frames and bare frame were estimated for the trial performance based design of the masonry infilled $\mathrm{R} / \mathrm{C}$ frames by modelling the frame structures as equivalent single-degree-of-freedom systems wherein the stiffness of the system is estimated from the idealized trilinear capacity curve of the infilled frame obtained from the pushover analysis. The yield strength reduction factors for the $\mathrm{R} / \mathrm{C}$ frames are obtained from the structural ductility factors for the corresponding time periods using the relationships proposed by Newmark and Hall [13]. The procedure for calculating the other design variables of the proposed method has been discussed in the earlier sections of the paper. Figure 3 displays the dimensions and reinforcement details of $\mathrm{R} / \mathrm{C}$ frame elements obtained from the first trial of PBD using the proposed energy approach for a target drift of $2 \%$ for the different infill panel distributions

\subsection{Nonlinear pushover analysis of the trial performance based designs of masonry infilled $\mathrm{R} / \mathrm{C}$ frames}

Pushover analyses of the PBDs of the infilled frames were performed to verify the elastic rotations (i.e. yield drifts) of the frames that were assumed in the proposed energy based plastic design procedure. The yield drifts computed from the pushover analyses are also mentioned in Table 1. It is evident from the table that the assumed elastic rotations are in close agreement with the computed yield drifts. It is also worthwhile to note that the normalized peak lateral forces for the 

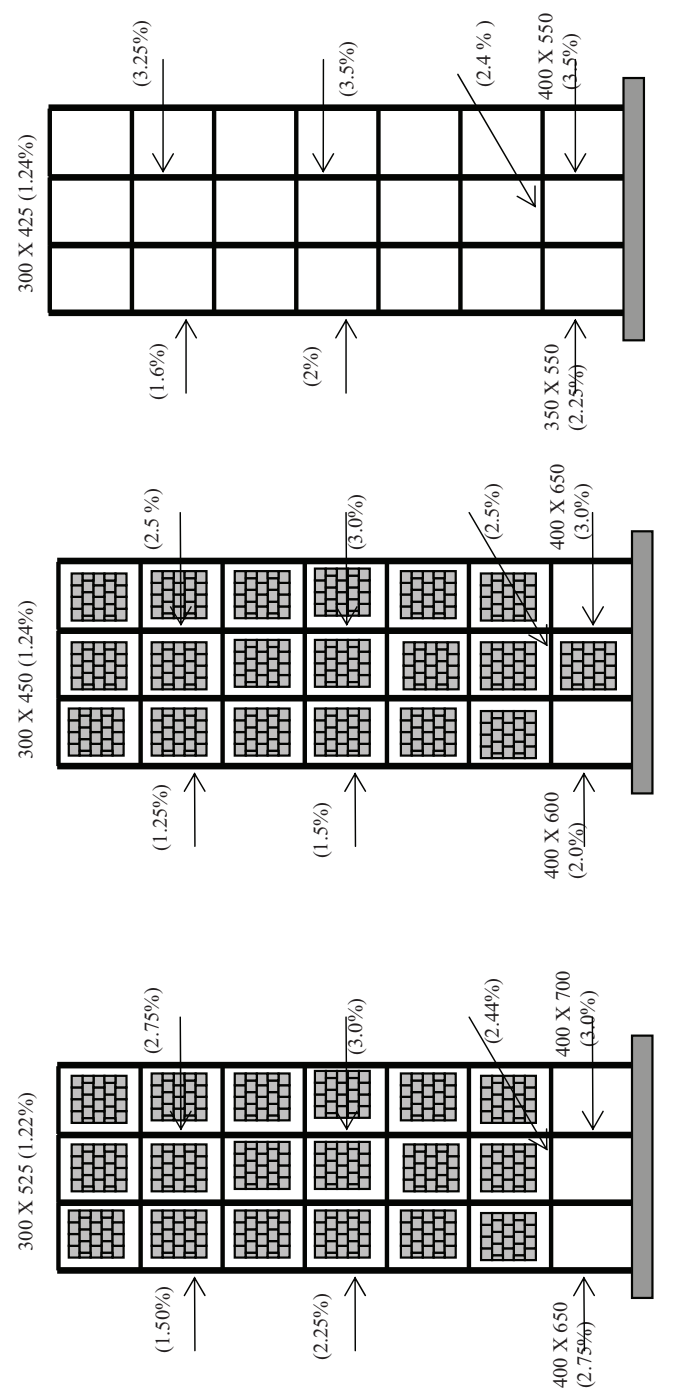

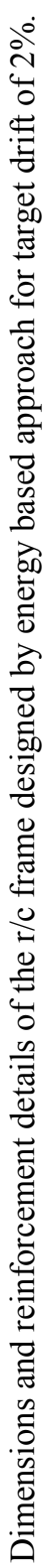

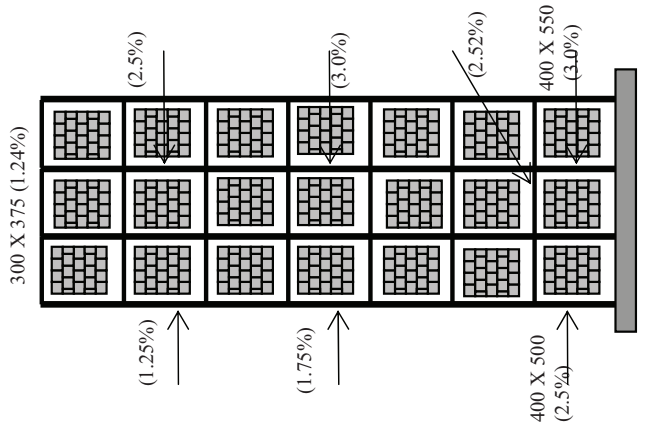

弟 
trial performance based designs of the masonry infilled R/C frames determined from the pushover analyses show reasonably good agreement with the design seismic base shear coefficients obtained from the proposed energy based plastic design procedure.

\section{Displacement based seismic analysis of trial performance based designs of masonry infilled $\mathrm{R} / \mathrm{C}$ frames}

In order to evaluate the seismic performance of the frames designed for the different target drift levels using the proposed procedure, non-linear dynamic analyses were performed using rational and realistic hysteretic models of the $\mathrm{R} / \mathrm{C}$ frame elements and masonry infill panels [10]. The non-linear dynamic analysis was performed using eight recorded earthquake ground acceleration records and one synthetic accelerogram. The recorded earthquake ground motions of Bhuj (India, 2001), El Centro (1940), San Fernando (1971) and Chile (1985) earthquakes considered in the dynamic analysis are far-field ground motions, while the Northridge (1994), Tabas (Iran, 1978), Erzincan (Turkey, 1992) and Chi Chi (Taiwan, 1999) earthquake ground motions are near-field or near-fault ground motions. All the recorded ground motions used for the dynamic analysis were scaled to achieve the same intensity as that of the ideal design level (design basis) earthquake specified by the current Indian seismic design code. Using the definition of spectrum intensity by Housner [14] the synthetic ground motion was artificially generated to be compatible with the design response spectrum provided by the Indian seismic design code with an intensity equal to that of the ideal design level earthquake specified by the code. Figure 1(c) displays the pseudo-velocity response spectra of the scaled earthquake ground motion records used for the dynamic analysis. The figure also shows the idealized pseudo-velocity response spectrum conforming to current Indian seismic design criteria.

\subsection{Results of seismic analysis of code compliant masonry infilled R/C frames}

The variations of the peak normalized inter-story drifts in percentage terms over the height of the code-compliant designs of the masonry infilled $\mathrm{R} / \mathrm{C}$ frame predicted by the non-linear dynamic analysis is shown in Fig 4(a). It can be observed from the figure that the maximum interstory drifts of frame with a 'soft' ground story range from $2.5 \%$ to $6 \%$. The maximum inter-story drifts for the frame with a partially infilled ground story are marginally lower. In contrast, the maximum inter-story drifts of the completely infilled frame ranges between $1 \%$ and $4 \%$ for all the earthquake ground motions with the exception of one for which the maximum inter-story drift is $6 \%$. The maximum inter-story drifts of the bare frame display a similar range as the corresponding completely infilled frame. The maximum inter-story drifts for the bare frame lie between $1 \%$ and $4 \%$ for all the earthquake ground motions with the exception of one for which the maximum inter-story drift is as large as $8 \%$. Figure 4(a) indicates that the 
prevalent force based design methodology followed by the current generation of seismic design codes largely disregard limitation of inter-story drifts and the related seismic damage.

\subsection{Results of seismic analysis of the trial performance based designs of masonry infilled $\mathrm{R} / \mathrm{C}$ frames for different target drifts}

The plots of variation of the peak normalized inter-story drifts in percentage terms over the height of the trial PBD of the R/C frame designed for a target drift of $2 \%$ as predicted by the non-linear dynamic analysis is shown in Figure 4(b). It is apparent from Figure 4(b) that the maximum inter-story drifts of the trial PBDs of the $\mathrm{R} / \mathrm{C}$ frame are within the target drift of $2 \%$ for all stories with the only exception of the bare frame in which the inter-story drift at the top level marginally exceeds the target drift. From the results presented in Figure 4(b), it can be concluded that the first trials of PBD of the masonry infilled $\mathrm{R} / \mathrm{C}$ frames meet the target performance level for each distribution of masonry infill panels considered in the study. Hence, a second trial by refining the design is not required for any frame. The figure also shows that the application of the proposed procedure is successful in limiting the inter-story drifts within the target drift of $2 \%$ under the influence of near-field earthquakes as well far-field earthquakes. Therefore, it is hypothesized that the proposed performance based design methodology using the energy approach can be effectively implemented for achieving the desired performance level in masonry infilled $\mathrm{R} / \mathrm{C}$ frames under near-field earthquakes as well. Moreover, further enhancement in seismic performance may be achieved by selecting a lower target drift in the proposed energy based plastic design procedure, for e.g. a target drift of $1 \%$ corresponding to immediate occupancy performance limit state.
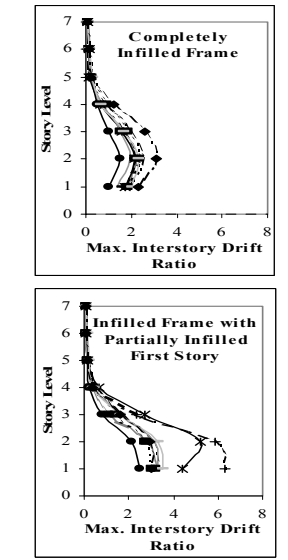

(a)

Figure 4:
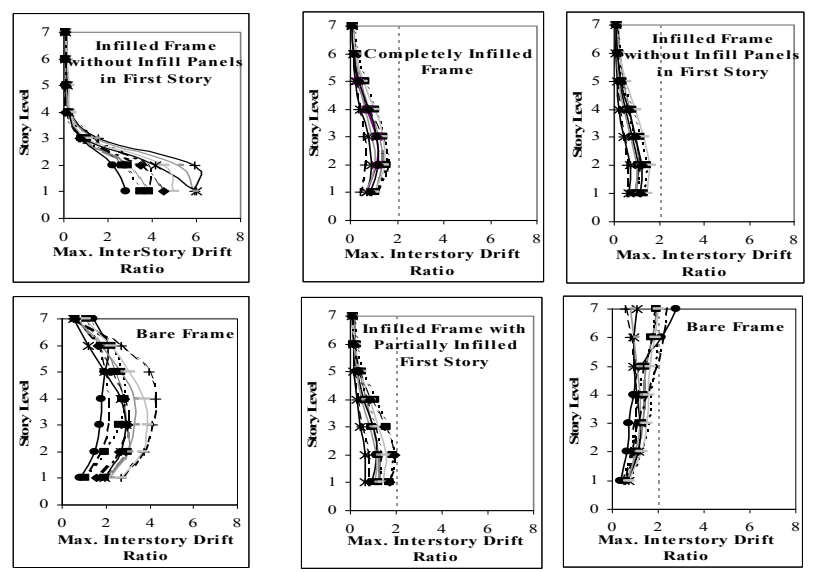

(b)

Peak normalized inter-story drifts (\%) of the r/c frame designed using (a) code specified force based design procedure and (b) energy based plastic design procedure for target drift of $2 \%$. 


\section{Conclusions}

The paper presents a plastic design procedure based on the energy balance concept for performance based seismic design of multi-story multi-bay masonry infilled reinforced concrete $(\mathrm{R} / \mathrm{C})$ frames subjected to near-field earthquakes considering the commonly implemented distributions of masonry infill panels over the frame elevation. The results of non-linear dynamic analyses of the codecompliant designs of the masonry infilled $\mathrm{R} / \mathrm{C}$ frames lead to the conclusion that the prevalent force based design methodology provided by the current generation of seismic design codes is inherently deficient in controlling the inter-story drifts and the related seismic damage under earthquake loads. An inherent limitation of the force based seismic design criteria specified by the present generation of seismic design codes is that the maximum plastic deformations are disregarded in the design formulation. The only specification in the seismic design criteria that considers the displacement demand on the structure is the check on drift limitations, which is accomplished by linear elastic methods. The incentives for retaining linear elastic analysis procedures in the current seismic design practice may be the simplicity of linear analysis techniques and the prevalent familiarity of engineers with force based design. Moreover, the current seismic design codes do not provide any explicit recommendations or guidelines that enable the engineer to predict the seismic performance of the final design or evaluate the margin of life safety achieved by conforming to the code specifications. The provision of strength reduction factor in the formulation for seismic base shear in the current seismic design codes implicitly assumes that the structure is capable of several cycles of inelastic deformation without loss of lateral strength due to intrinsic ductility of the structure. However, the force based design formulation does not specify any limitation on the maximum plastic drift of the structure.

The results of non-linear dynamic analyses of the trial performance based designs of the masonry infilled $\mathrm{R} / \mathrm{C}$ frames with the various practically relevant distributions of masonry infill panels over the frame elevation lead to the conclusion that the first trials of performance based design of the masonry infilled $\mathrm{R} / \mathrm{C}$ frames meet the target performance level for each distribution of masonry infill panels over the frame elevation considered in the study for all practical purposes. Hence, a second trial by refining the design may not be required for any distribution of masonry infill panels. A more important conclusion that can be derived from the results of non-linear dynamic analyses is that the application of the proposed energy based plastic design procedure for performance based seismic design is equally successful in limiting the inter-story drifts of the masonry infilled $\mathrm{R} / \mathrm{C}$ frames within the specified target drifts under the influence of near-field earthquakes. The proposed performance based design methodology using the energy approach offers an engineering solution to the inverse problem of determining the design dimensions and reinforcement of the $\mathrm{R} / \mathrm{C}$ frame members in a masonry infilled $\mathrm{R} / \mathrm{C}$ framed buildings that are required to achieve the specified performance objective for the building structure for a given seismic hazard level. The proposed energy approach is more rational and realistic for performance based seismic design of building structures subjected to 
near-field as well as far-field earthquakes since the approach is based on the fundamentals of energy balance.

\section{References}

[1] Yang, J. N., and Agrawal, A. K., "Semi-Active Hybrid Control for Nonlinear Buildings against Near-Field Earthquakes." Engineering Structures, Vol.94, 2002, pp.271-280.

[2] Roberts, M. W., and Lutes, L. D., 2003 "Potential for Structural Failure in the Seismic Near-field.” Journal of Engineering Mechanics, ASCE, V.129, No.8, 2003, pp.927-934.

[3] Leelataviwat, S., Goel, S.C., and Stojadinovic, B., "Energy-Based Seismic Design of Structures using Yield Mechanism and Target Drift." Journal of Structural Engineering, V.128, No.8, 2002, pp.1046-1054.

[4] Housner, G.W., "Limit Design Of Structures To Resist Earthquakes." Proceeding of 1st world conference on earthquake engineering, Earthquake Engineering Research Institute, Oakland, California, 5, 1956, pp.1-13.

[5] Kato, B., and Akiyama, H., " Seismic Design of Steel Buildings" Journal of Structural Division, ASCE, V.108, No. 8, 1982, pp.1709-1721.

[6] Akiyama, H., "Earthquake-Resistant Limit-State Design of Buildings." University of Tokyo Press, Tokyo, 1985.

[7] Lee, S.S., and Goel, S.C., "Performance Based Design Of Steel Moment Frames Using Target Drift And Yield Mechanism." Research Report UMCEE 01-17, The University of Michigan, Ann Arbor, Michigan, 2001.

[8] BIS. "IS 1893-2002 (Part 1): Indian Standard Criteria for Earthquake Resistant Design of Structures, Part 1-General Provisions and Buildings." Bureau of Indian Standards, 2002.

[9] Madan, A., Reinhorn, A. M., Mander, J. B., Valles, R., "Modeling of Masonry Infill Panels for Structural Analysis." Journal of Structural Engineering, V.123, No.10, 1997, pp.1295-1302.

[10] Valles, R. E., Reinhorn, A. M., Kunnath, S. K., Li, C., and Madan, A., "IDARC Version 4.0 - A Program for the Inelastic Damage Analysis of Buildings.” Technical Report NCEER-96-0010, SUNY/Buffalo, 1996.

[11] ATC-40., "Seismic Evaluation and Retrofit of Concrete Buildings." Report SSC 96-01, California Seismic Safety Commission, Applied Technology Council, CA, USA, 1996.

[12] FEMA-356 "Prestandard and Commentary for Seismic Rehabilitation of Buildings", Federal Emergency Management Agency (FEMA), Washington D. C., USA, 2000.

[13] Newmark, N.M., and Hall, W.J., "Earthquake Spectra and Design." Earthquake Engineering Research Institute, Oakland,California, 1982.

[14] Housner, G. W., "Behavior of structures during earthquakes." Journal of Engineering Mechanics, ASCE, V.85, No.4, 1959, pp.109-129. 